\title{
Çocuk ve Ergen Cinsel İstismarlarının Değerlendirilmesi Assessment of Sexual Abused Child Anadolescent
}

\author{
${ }^{1}$ Beyza Urazel, ${ }^{2}$ Saniye Tülin Fidan, ${ }^{1}$ Tarık Gündüz, ${ }^{1}$ Meryem Şenlikli, \\ ${ }^{2}$ Bengisu Özçivit Asfuroğlu \\ ${ }^{1}$ Eskişehir Osmangazi Üniversitesi Tıp Fakültesi Adli Tıp Anabilim Dalı, Eskişehir \\ ${ }^{2}$ Eskişehir Osmangazi Üniversitesi Tıp Fakültesi Çocuk ve Ergen Ruh Sağlığı ve Hastalıkları \\ Anabilim Dalı, Eskişehir
}

Öz: Cinsel istismar sık görülen bir halk sağlığı sorunudur ve bu olguların sadece $\% 15$ kadarı ortaya çıkmaktadır. Cinsel istismar çocuk ve ergenler üzerinde yıkıcı etkilere neden olmaktadır. Önleme ve tedavi planlaması açısından olguların demografik özelliklerinin incelendiği ayrıntılı çalışmalara gereksinim duyulmaktadır. Bu çalışmada, cinsel istismar mağduru olguların sosyodemografik özellikleri ve cinsel istismar olayının ön plana çıkan özelliklerinin değerlendirilmesi amaçlanmıştır. ESOGÜ Tıp Fakültesi Çocuk Adli Değerlendirme Birimi tarafından 01.01.2012-31.03.2014 tarihleri arasında değerlendirilen cinsel istismar mağduru 135 olgu çalışmaya dahil edilmiştir. Bu olguların tıbbi dosyaları ile adli raporları geriye dönük olarak incelenmiștir. Olguların \%79,3'ünün kız olup, cinsel istismar olayının \%41,5'inin fiziksel temas (Dokunma/öpme) şeklinde gerçekleştiği, istismarcının çoğunlukla çocuğun tanıdığı biri (\%71.9) olduğu ve eylem için çocuğu zorladığı $(\% 61,5)$, istismarcıların sadece $\% 28,1$ 'inin yabancı kişiler olduğu saptanmıştır. Çocuğun cinsel istismarı ile ilgili olarak toplumun her kesiminin bilgilendirilmesi ve her ortamda (ev, okul, sosyal çevre vb.) koruyucu önlemlerin alınması gerekmektedir. Çocuğun cinsel istismarının olası nedenlerinin anlaşılması ve önleyici yaklaşımların geliştirilebilmesi için işbirliği yapılması ve olguların ayrıntılı incelendiği çalışmaların sonuçları önemlidir.

Anahtar Kelimeler: cinsel istismar, çocuk, ergen, istismar.

Urazel B., Fidan Saniye T., Gündüz T., Şenlikli M., Asfuroğlu Özçivit B. (2017) Çocuk ve Ergen Cinsel İstismarlarının Değerlendirilmesi. Osmangazi Tip Dergisi, 39(2):18-25, DOI: 10.20515/otd.308058.

\begin{abstract}
Sexual abuse is a common public health problem and only 15\% of these cases arises. Sexual abuse leads to devastating effect on child and adolescents. More and further studies are needed for prevention and treatment. In this study, it's aimed to evaluate sociodemographic characteristics of sexual abuse victims and characteristic features of sexual abuse.135 victims of sexual abuse who were evaluated at department of forensic medicine and child and adolescent psychiatry were included in the study. Forensic reports and medical files of these cases were studied retrospectively. $79,3 \%$ of cases were female and touching/kissingbehaviors were determined in $\% 41,5$ sexual abuse events. Violence was the most common method $(61,5 \%)$ used by perpetrators. Only $28,1 \%$ of perpetrators were stranger.All sections of society should be informed about sexual abuse and measures must be taken at each step. Therefore, cooperation between different professional groups and supported by different studies is important.
\end{abstract}

Keywords: sexual abuse, child, adolescent, abuse

Urazel B., Fidan Saniye T., Gündüz T., Şenlikli M., Asfuroğlu Özçivit B. (2017) Assessment of sexual abused child anadolescent. Osmangazi Journal of Medicine, 39(2):18-25, DOI: 10.20515/otd.308058. 


\section{Giriş}

Cinsel istismar, rıza yaşı altındaki bir çocuğun cinsel yönden olgun olan bir erişkin tarafindan cinsel doyuma yol açacak şekilde kullanılması ya da bu olaya göz yumulması şeklinde tanımlanmaktadır (1-2). Cinsel ilişki kurma, cinsel ilişki kurmaya teşebbüs etme, genital bölgeleri okşama, erişkinlerin cinsel ilişkilerine ve pornografiye maruz bırakma, yine pornografi ve fuhuş için kullanma cinsel istismar davranışları olarak adlandırılmaktadır $(3,4) . \quad \mathrm{Bu}$ davranışların mutlaka şiddet içermesi gerekmez ve çocuğun rızasının olup olmadığına bakılmaz (5).

Cinsel istismara maruziyet y1llarca sürmekle beraber genellikle gizli kalmaktadır. Sik görülen cinsel istismar olgularının sadece $\% 15$ 'inin bildirildiği ve ortaya çıtığ bilinmektedir (6). $\mathrm{Bu}$ olguların gizli kalmasında, çocuğun uğradığı davranışı yanlış olarak algılayamıor olması, hoş olmayan hatıraları bastırmas1 ya da unutmak istemesi, olayı ve ayrıntılarını anlatmada yeterli iletişim becerilerine sahip olmamas gibi nedenler önemli rol oynamaktadır (7). Utanç, suçluluk tepkileri nedeniyle bildirim azlığı, yaygınlık çalışmalarının genellikle çocukluğunda istismara uğramış yetişkinlerle yapılması ve kişi için cevaplaması zor, özel yaşantıyla ilgili sorular içermesi oranlar arasındaki büyük

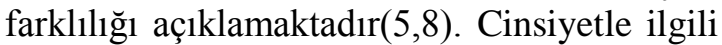
bildirilen oranlar arasında farklılıklar olup, cinsel istismar yaygınlığının kadınlarda \%1217 , erkeklerde \%5-8 olduğu bildirilmektedir (6).

Düşük sosyoekonomik düzey, anne-baba arasında ve ebeveynler ile çocuk arasındaki zayıf ilişki, koruyucu anne ve babanın olmayışı, çocukta zeka geriliği gibi psikiyatrik bir bozukluğun bulunușu cinsel istismar riskini arttırmaktadır $(5,9)$.

Ensest açısından, babanın alkol bağımlılı̆̆ının olması, annenin kronik bir hastalığının olması ya da evi terk etmesi, yetişkinlerin çocukla aynı yatağı paylaşması, kı çocuklarının babadan ayrı yaşaması, aile bireylerinde bulunan psikiyatrik bozukluklar, annenin gece çalışıyor olması, ebeveynlerin kendi ailelerinde ensest ilişkinin bulunması risk etmenleri arasında yer almaktadır $(5,9)$.
Çocuğun cinsel istismarının, çocuk üzerinde yıkıcı etkilere neden olduğu ve bu etkilerin cinsellik ile ilgili sorunlar, güven duygusunun zarar görmesi, güçsüzlük ya da çaresizlik duygusu ve damgalanma ilgili düşünceler olarak 4 başlık altında toplanabileceği belirtilmektedir (1).

Çocukluk döneminde yaşanan cinsel istismarın, uzun dönemde de olumsuz etkileri söz konusudur. Kaygı bozuklukları, dikkat eksikliği ve hiperaktivite bozukluğu, ikincil enürezis ve enkoprezis, disosiasyon/ çözülme, depresyon, öfke tepkileri ve zayıf dürtü kontrolü, kişiler arası ilişki kurma ve sosyal ilişkileri sürdürme becerilerinde sorunlar, yüksek riskli cinsel eylemlerde bulunma davranışları cinsel istismara maruz kalan çocuklarda sık görülen ruhsal durumlardır (6).

Cinsel istismara maruz kalmış olan bir çocuğun, bulunduğu güvensiz ortamdan anında uzaklaştırılması gerekmektedir. Olay sonrasında öykü deneyimli bir ruh sağlığ çalışanı (Çocuk Ruh Sağlığı ve Hastalıkları Uzman1, Psikolog, Sosyal Hizmet Uzmanı Çocuk Gelişim Uzmanı) tarafından alınmalı, çocuk ile yalnız görüşülmeli, yargılayıcı olmaktan kaçınılmalıdır. Açık uçlu soruların ardından eğer açıklığa kavuşmayan konular var ise özel sorular sorulmalıdır. Görüşme esnasında çocuğun davranışları da gözlemlenerek kaydedilmelidir. Öykü alınırken tüm ayrıntılar, çocuğun tıbbi geçmişi, ailede yaşanan benzer olaylar sorgulanmalıdır (5).

Cinsel istismar olgularında bireysel terapiye ek olarak grup ve aile terapileri de uygulanmaktadır. Olgulara destekleyici yaklaşım yapılmalı, özellikle aile içi cinsel istismar olgularında doktor ile çocuk arasındaki ilişkinin çocuğun kurduğu ilk sağlıklı ilişki olabileceği göz önünde bulundurulmalıdır (6).

Çocuğun cinsel istismarını önlemede, birinci düzey çalışmalar;çocukların bilgilendirilmesini, ikinci düzey çalışmalar; risk etmenlerinin ve gruplarının belirlenmesini, istismara uğrayan çocuğun güvenliğinin sağlanması ve yasal düzenlemelerin yapılmasını, üçüncü düzey çalışmalar ise istismara uğrayan çocukta kısa 
ve uzun dönemde ortaya çıkabilecek etkilerin azaltılmasına yönelik klinik iyileştirici çalışmaları içermektedir (1).

Çocuk cinsel istismarının yönelik koruyucu hizmetlerin geliştirilmesi ve uygun tedavi planlamasının yapılabilmesi için olguların sosyodemografik özelliklerinin incelendiği ayrıntılı çalışmalara ihtiyaç vardır. $\mathrm{Bu}$ çalışmada, Çocuk Adli Değerlendirme Birimine başvuran cinsel istismara maruz kalmış çocuk ve ergenlere ait sosyodemografik bulgular analiz edilelerek yazın eşliğinde tartışılmıştır.

\section{Gereç ve Yöntemler}

Çalışmadaki veriler, ESOGÜ Tıp Fakültesi Çocuk Adli Değerlendirme Birimince 01.01.2012-31.03.2014 tarihleri arasinda düzenlenen 135 olguya ait adli rapor ve tıbbi kayıtların geriye dönük incelenmesi ile elde edilmiştir. Olguların sosyodemografik özellikleri, istismar ve istismarciya ait bilgiler ile ruhsal durum muayenesi sonuçları kaydedilmiştir.

\section{Istatistiksel Analiz}

$\mathrm{Bu}$ çalışmada sürekli değişkenler ortalama \pm standart sapma (ss) olarak gösterildi. Kategorik değişkenler için Ki-kare testi ile analiz edildi ve frekans ve yüzde şeklinde gösterildi. İstatistiksel analizler için SPSS 18.0 (SPSS Inc., Chicago, IL, USA) kullanıldı. İstatistiksel önemlilik düzeyi $\mathrm{p}<0.05$ olarak kabul edildi.

\section{Bulgular}

Çalışmaya cinsel istismar mağduru olduğu iddia edilen 2012-2014 y1lları arasinda başvuran 4-17 yaş aralığında, 135 olgu dahil edilmiş olup, yaş ortalaması $13,0 \pm 3,3$ idi. 12 yaş altındaki cocuk olguların oran $1 \% 26,7,12$ 15 yaş aralığındaki cocuk olguların oranı $\% 47,4,15$ yaş ve üstündeki ergenlerin oranı $\% 25$, olarak tespit edilmiştir. 12 yaş altı çocuk olguların \%27,8'inin erkek, \%72,2'sinin kız olduğu, 12 yaş ve üstü ergen olguların $\% 18,2$ 'sinin erkek, \%81,8'inin k1z olduğu saptanmış olup cinsiyete göre yaş grupları arasında istatiksel olarak anlamlı bir fark olmadığ 1 tespit edilmiştir (sırasıly $\mathrm{p}=0,42$ ve $\mathrm{p}=0,45)$ (Tablo 1).
Cinsel istismar mağduru erkeklerin yaş ortalamas1 12,4 $\pm 3,4$, kızların ise 13,2 $\pm 3,3$ dür. Cinsiyete göre yaş ortalamaları arasında istatiksel olarak anlamlı bir fark bulunamamıştır $(\mathrm{p}=0,24)$.

12 yaş altı grupta erkek olguların yaş ortalamas1 9,4 $\pm 2,4$, kızların 9,2 $\pm 2,6$ dir. 12 yaş ve üstü grupta erkeklerin yaş ortalamas1 $14,4 \pm 1,6$, k1zların 14,8 $\pm 1,6$ dır. Her iki grupta da cinsiyete göre yaş ortalamaları arasında istatiksel olarak anlamlı bir fark olmadığ görülmüş̧ür (sırasılyla $\mathrm{p}=0,80$ ve $\mathrm{p}=0,40$ ) .

Olguların \%48,1'i ilköğretim, \%25,2'si lise öğrencisi olup, \%25,2'sinin okula devam etmediği belirlenmiştir.

Cinsel istismarın meydana geliş şekilleri incelendiğinde, tüm olguların \%26,7'sında vajinal penetrasyon, $\% 18,5$ 'sinda anal penetrasyon, \%41,5'inde dokunma/öpme, $\% 5,2$ 'sinde cinsel organın sürtülmesi, $\% 2,2$ 'sinde cinsel organ gösterilmesi, $\% 5,9$ 'unda hem anal hem vajinal penetrasyon hikayesi olduğu saptanmıştır. Yaş gruplarına göre cinsel istismarın meydana geliş şekilleri arasında istatistiksel olarak anlamlı bir fark olduğu 12 yaş üstünde anal ve vajinal penetrasyonun daha sik olduğu saptanmıştır. $\left(\chi^{2}=23,183, p=0,001\right)$

Olguların \%77,0'1 bir defa, \%23,0'1 birden çok kez cinsel istismara maruz kalmış olup, istismar olaylarının \%87,4'ünde bir istismarc1 bulunurken, \%12,6'sinda birden çok istismarcı bulunmaktadır. Yaşa göre cinsel istismara maruz kalma sayıları Tablo 1'de verilmiştir.

İstismarcının kullandığ1 yöntemler göz önüne alındığında, zorlama \%61,5 oranında ilk sırada yer alırken, bir şey gösterme, bir şey verme ile kandırma \%25,9 oranıla ikinci sırada yer almaktadır. Evlenme vaadinin olmas1 \%5,9, porno görüntü izletme $\% 0,7$, çekilen görüntülerin tehdit olarak kullanılması $\% 2,2$ oranında tespit edilmiştir. 12 yaş üzerindeki olgulardan 5 'i $(\% 3,7)$ kendi isteği bulunduğunu ifade etmiş̧tir. Yaş grubuna göre istismarcının kullandığı yöntemler arasında istatistiksel olarak anlamlı fark bulunmuştur $\left(\chi^{2}=15,385, \mathrm{p}=0,031\right)$ (Tablo 1$)$. 
Tablo 1.

Yaş Gruplarına göre Değişkenlerin Dağılımı

\begin{tabular}{|c|c|c|c|c|c|c|c|c|}
\hline \multirow[t]{2}{*}{ Değişkenler } & & \multicolumn{2}{|c|}{ Yaş $<12$} & \multicolumn{2}{|c|}{ Yaş $\geq 12$} & \multicolumn{2}{|c|}{ Toplam } & \multirow[t]{2}{*}{$\mathrm{p}$} \\
\hline & & $\mathrm{n}$ & $\%$ & $\mathrm{n}$ & $\%$ & $\mathrm{n}$ & $\%$ & \\
\hline \multirow{2}{*}{ Cinsiyet } & Erkek & 10 & 27.8 & 18 & 18.2 & 28 & 20.7 & \multirow{2}{*}{0.42} \\
\hline & $\mathrm{K} 1 \mathrm{z}$ & 26 & 72.2 & 81 & 81.8 & 107 & 79.3 & \\
\hline \multirow{4}{*}{ Eğitim } & Okumuyor & 6 & 16.7 & 28 & 28.3 & 34 & 25.2 & \\
\hline & Anaokulu & 2 & 5.6 & 0 & 0 & 2 & 1.5 & \\
\hline & İlköğretim & 28 & 77.8 & 37 & 37.4 & 65 & 48.1 & \\
\hline & Lise & 0 & 0 & 34 & 34.3 & 34 & 25.2 & \\
\hline \multirow{6}{*}{ İstismar şekli } & Anal penetrasyon & 10 & 27.8 & 15 & 15.2 & 25 & 18.5 & \multirow{6}{*}{0.001} \\
\hline & Vajinal penetrasyon & 2 & 5.6 & 34 & 34.3 & 36 & 26.7 & \\
\hline & Dokunma /öpme & 16 & 44.5 & 40 & 40.4 & 56 & 41.5 & \\
\hline & Organ sürtülmesi & 4 & 11.1 & 3 & 3.0 & 7 & 5.2 & \\
\hline & Organ gösterilmesi & 3 & 8.3 & 0 & 0 & 3 & 2.2 & \\
\hline & $\begin{array}{l}\text { Vajinal ve anal } \\
\text { penetrasyon }\end{array}$ & 1 & 2.8 & 7 & 7.1 & 8 & 5.9 & \\
\hline \multirow{2}{*}{ İstismar sayıs1 } & Bir defa & 27 & 75.0 & 77 & 77.8 & 104 & 77.0 & \multirow{2}{*}{0.73} \\
\hline & Çok sayıda & 9 & 25.0 & 22 & 22.2 & 31 & 23.0 & \\
\hline \multirow{2}{*}{$\begin{array}{l}\text { İstismarc1 } \\
\text { say1s1 }\end{array}$} & Bir kişi & 32 & 88.9 & 86 & 86.9 & 118 & 87.4 & \multirow{2}{*}{0.81} \\
\hline & Birden fazla kişi & 4 & 11.1 & 13 & 13.1 & 17 & 12.6 & \\
\hline \multirow{6}{*}{$\begin{array}{l}\text { İstismar } \\
\text { Yöntemi }\end{array}$} & Zorlama & 21 & 58.3 & 62 & 62.6 & 83 & 61.5 & \multirow{6}{*}{0.031} \\
\hline & Evlenme vaadi & 1 & 2.8 & 7 & 7.1 & 8 & 5.9 & \\
\hline & $\begin{array}{l}\text { Bir şey gösterme- } \\
\text { verme ile kandırma }\end{array}$ & 13 & 36.1 & 22 & 22.2 & 35 & 25.9 & \\
\hline & Porno izletme & 1 & 2.8 & 0 & 0 & 1 & 0.7 & \\
\hline & Görüntü ile tehdit & 0 & 0 & 3 & 3.0 & 3 & 2.2 & \\
\hline & Kendi isteği & 0 & 0 & 5 & 5.1 & 5 & 3.7 & \\
\hline \multirow{5}{*}{ İstismarc1 } & Yabanc1 & 11 & 30.6 & 27 & 27.3 & 38 & 28.1 & \multirow{5}{*}{0.101} \\
\hline & Aile içi & 8 & 22.2 & 7 & 7.1 & 15 & 11.1 & \\
\hline & Akraba & 1 & 2.8 & 2 & 2.0 & 3 & 2.2 & \\
\hline & Tanıdık & 12 & 33.3 & 41 & 41.4 & 53 & 39.3 & \\
\hline & Akran & 4 & 11.1 & 22 & 22.2 & 26 & 19.3 & \\
\hline \multirow{5}{*}{$\begin{array}{l}\text { İstismarın } \\
\text { ortaya çıkışı }\end{array}$} & $\begin{array}{l}\text { Mağdur } \\
\text { itirafi/anlatması }\end{array}$ & 13 & 36.1 & 51 & 51.5 & 64 & 47.4 & \multirow{5}{*}{0.87} \\
\hline & Ailenin şüphesi & 14 & 38.9 & 24 & 24.2 & 38 & 28.1 & \\
\hline & Arkadaş itirafı/şüphesi & 4 & 11.1 & 14 & 14.1 & 18 & 13.3 & \\
\hline & Görgü tanı̆̆g ifadesi & 5 & 13.9 & 5 & 5.1 & 10 & 7.4 & \\
\hline & Gebelik & 0 & 0 & 5 & 5.1 & 5 & 3.7 & \\
\hline
\end{tabular}

İstismarcıların sadece \%28,1'inin yabanc1 kişiler olduğu, \%52,6'sının aile içi, akraba ve tanıdık kişilerden oluştuğu, \%19,3'ünün yine mağdurun tanıdığı akranları olduğu belirlenmiştir (Tablo 1). Saldırganın tanıdık olup olmadığına göre yaş grupları değerlendirildiğinde sadece $0-6$ yaş arası olgular ile diğer yaş grubu olgular arasında anlamlı bir fark olduğu görülmüş $(\mathrm{p}=0,04), 0$ 6 yaş grubunda saldırganın $\% 77$ oranında tanıdık biri olduğu tespit edilmiştir.

Cinsel istismarın \%47,4'ünün mağdurun kendisinin aileye ya da adli mercilere olay anlatmas1, \%28,1'inde ailenin durumdan şüphelenmesi， \%13,3'ünde olay1 öğrenen arkadaşların itirafları, \%7,4'ünde görgü tanıklarının ifadeleri ile ortaya çıktığı tespit edilmiștir. $\mathrm{Bu}$ olguların \%3,7'sinde gebelik tespiti ile cinsel istismarın belirlendiği görülmüştür (Tablo 1).

Cinsel istismarların \%34,0'ının aynı gün, $\% 50,4$ 'ünün ilk 3 ay içerisinde, \%15,6'sının da 3 aydan daha uzun sürede adli makamlara yansıdığı, olguların \%33,4'ünün olaydan sonraki ilk 3 ay, \%21,5'inin 4-6 ay, $\% 25,9$ 'unun 7-12 ay içerisinde ve \%19,2'sinin de 13 ay ve sonrasinda psikiyatrik muayene 
için müracaat ettirildiği belirlenmiştir (Tablo 2-3).

İstismar olaylarının \%20,7'si açık alanda, \%74,1'i kapalı mekanda, \%5,2'si araç içinde gerçekleşmiştir. Kapalı mekanlar içerisinde, istismar olayının en sık gerçekleştirildiği yer istismarcının evi olarak saptanmıştır.
Olguların \%16,3’ünde farklı düzeylerde zeka geriliği bulunduğu tespit edilmiştir.

ESOGÜ Tıp Fakültesi Çocuk Ruh Sağlığı ABD'da yapılan ruhsal değerlendirme ve takipleri sonucunda, olguların \%27,4'ünde Travma Sonrası Stres Bozukluğu (TSSB), \%4,4'ünde TSSB ile depresyon, \%3,7'sinde depresyon, \%2,2'sinde anksiyete bozukluğu tanılarının geliştiği bulunmuştur (Tablo 4).

Tablo 2.

Adli başvuru süresi

\begin{tabular}{lcc}
\hline Adli makama başvuru süresi & sayı & $\%$ \\
\hline Olay günü & 46 & 34.0 \\
$\leq 3$ ay & 68 & 50.4 \\
$>3$ ay & 21 & 15.6 \\
Toplam & 135 & 100.0 \\
\hline
\end{tabular}

Tablo 3.

İstismar sonrası ruhsal muayeneye kadar geçen süre

\begin{tabular}{lcc}
\hline $\begin{array}{l}\text { Olay ile psikiyatrik muayene } \\
\text { arası geçen süre }\end{array}$ & sayı & $\%$ \\
\hline 3 ay & & 33.4 \\
$4-6$ ay & 45 & 21.5 \\
$7-12$ ay & 29 & 25.9 \\
$\geq 13$ ay & 35 & 19.2 \\
\hline
\end{tabular}

Yaş: ort:13.0 \pm 3.3

Tablo 4.

Ruhsal Muayene sonuçlarına göre tanılar

\begin{tabular}{lcc}
\hline Psikiyatrik tanı & sayı & $\%$ \\
\hline Yok & 84 & 62.2 \\
TSSB & 37 & 27.4 \\
Depresyon & 5 & 3.7 \\
TSSB+Depresyon & 6 & 4.4 \\
Anksiyete bozukluğu & 3 & 2.2 \\
Toplam & 135 & 100.0 \\
\hline
\end{tabular}

\section{Tartışma}

Ülkemizde çocuk cinsel istismarı üzerine yapılan bir çalışmada yaş ortalaması $12 \pm 4$ olarak tespit edilmiş (11), başka bir çalışmada ise olguların yaş ortalaması $13,2 \pm 3,1$ olarak tespit edilmiştir(12). Yaşın artmasıyla risk faktörlerinin de $\operatorname{arttığ1~belirtilmektedir~(13).~}$ Çalışmamızda yaş ortalaması yazındakine benzer şekilde 13,0 yaş civarında bulunmuştur (Tablo 5).

Tablo 5.

Zeka Durumunun Dă̆ılımı

\begin{tabular}{lcc}
\hline Zeka durumu & sayı & $\%$ \\
\hline Düşük & 22 & 16.3 \\
Normal & 113 & 83.7 \\
Toplam & 135 & 100.0 \\
\hline
\end{tabular}



Karadeniz Teknik Üniversitesi Tip Fakültesince yapılan ve cinsel istismar açısından 118 olgunun incelendiği çalışmada, kızların yaş ortalamasının $(11,1 \pm 3,3)$ erkeklerin yaş ortalamasına $(9,6 \pm 2,8)$ göre anlamlı derecede yüksek olduğu tespit edilmiştir (14). Yine başka bir çalışmada cinsel istismar mağduru kızların yaş ortalamas $13,2 \pm 3,2$ erkeklerin yaş ortalaması $10,7 \pm 3,0$ olarak tespit edilmiş ve arada istatistiksel olarak anlamlı bir fark olduğu belirtilmiştir (15). Bu çalışmada ise hem 12 yaş altı, 12 yaş ve üzeri ve tüm olguların yaş ortalamaları ile cinsiyetleri arasinda anlamlı bir fark bulunamamıştır $(\mathrm{p}>0,05)$. Tüm olgularda kızların yaş ortalaması $12,3 \pm 3,4$, erkeklerin yaş ortalaması $13,1 \pm 3,4$ olup diğer çalışmalara göre istismar mağduru çocuk ve ergenlerin 2-3 yaş daha büyük olduğu görülmektedir.

Çalışmalarda çocuk ve ergenlerde kızların daha yüksek oranda cinsel istismara maruz kaldıkları gösterilmiştir $(3,11,13,16)$. Çalışmamızda cinsel istismar mağduru olan çocuk ve ergenlerin \%79,3'ünün kız olduğu saptanmıș, kızların cinsel istismar açısından daha riskli grup oldukları görülmüştür. Tüm yaş gruplarında kız olgu sayısı yüksek olup cinsiyet açısından gruplar arası anlamlı bir fark yoktur.

Yine çalışmamızda olguların daha çok ilköğretim öğrencisi oldukları belirlenmiş olup yazında bildirilen ile uyumlu bulunmuştur $(3,17)$.

Çocuklar çok farklı şekillerde cinsel istismara maruz kalabilmektedir. Cinsel istismar, penetrasyonun da içinde olduğu fiziksel temasları içerebildiği gibi, fiziksel temas olmadan da gerçekleştirilebilir. Cinsel davranıșların ya da online görüntülerin izlettirilmesi, çocuk ve ergenlerin bu amaçla kullanılması da bu davranışlar içerisindedir (18). Cinsel istismarın türleri incelendiğinde en sık dokunma/öpme, ikinci siklıkla vajinal penetrasyon ve üçüncü sıklıkla anal penetrasyon görüldüğü bildirilmiştir $(3,11)$. $\mathrm{Bu}$ çalışmada, \%41,5 oranıly dokunma ve öpme ilk sırada yer alırken, $\% 26,7$ oranıla vajinal penetrasyon ikinci, $\% 18,5$ orantyla anal penetrasyon 3. sirada yer almaktadır.

Çalışmada yer alan olguların cinsel istismara maruz kaldıkları alanlar çok çeşitli olup, açık alanları, iş yeri, istismarc1 ve mağdurun evi, araç içleri, okul ile diğer kapalı mekanları kapsadığı görülmüştür. Olayın gerçekleştiği mekanlar ve özellikleri göz önüne alındığında cinsel istismarın çok çeşitli yerlerde meydana gelebileceği ve sadece belirli mekanlara özgü olmadığı göz önünde bulundurulmalıdır.

Yapılan çalışmalarda istismarcıların genellikle zor kullandıkları görülmüştür $(3,14,19)$. Çalışmamızda da istismarın gerçekleştiriliş yöntemi olarak zorlama \%61,5 oraniyla ilk sırada yer almaktadır. Olguların \%25,9'unda birşey verme, birşey gösterme şeklinde kandırılma hikayesi bulunduğu tespit edilmiştir. Çocukların kolay korkutulabildikleri ve kandırılabildikleri için istismar açısından risk altında oldukları belirtilmektedir (1). Yapılan çalışmalar pedofili tanıs1 olan hastaların zorlama yöntemini kullanmadıklarını, daha çok dokunma şeklinde temaslarda bulundukları, sonra bu dokunmaların uygunsuz dokunmalar şeklinde devam ettiği, porno izletme gibi davranıșlarda bulunduklarını göstermiștir $(3,14,19)$. Çalışmalarda tüm yaş gruplarında zorlama yönteminin ilk sirada yer almas1 cinsel istismarın sadece pedofilik olduğu düşünülen kişilerce gerçekleşmediğini, cinsel istismarda kişilere ait başka etkenlerin rol oynadığını göstermektedir.

İstismarcı çok büyük oranda çocuk ve ergen mağdurların aile içinden bir birey, akraba ve daha önceden bildiği kişilerdir $(1,3,5,11,17)$. Yaptığımız çalışmada istismar öykülerinin $\% 28,1$ 'inde istismarcinın yabanc1 olduğu, $\% 71,9$ 'unda istismarcinın aile bireyi, akraba, tanıdık kişi ve önceden tanıdığ 1 akranları olduğu belirlenmiştir.

Toplum içerisindeki bazı yanlış düşünceler, mağdurun yaşadığı suçluluk duygusu, çocuk mağdurların olayı tam olarak anlayıp ifade edememesi gibi durumlar mağdurların istismar olayını gizlemesine ya da açıklayamamasına neden olmaktadır $(3,20)$. Bunlara ek olarak, istismarcının mağdurun yakını veya akrabası olması, istismarcinın korunmak istenen biri olmas1, kimsenin bu duruma inanmayacak olduğunu düşünme gibi faktörler istismar olayının mağdurun ifadesi değil de başka sebeplerle ortaya çıkmasını açıklamaktadır (1). Çalışmada istismar olaylarının \%47,4'ünün mağdurun ifadesi sonucu ortaya çıktığı, diğer \%52,6 oranındaki istismar olayının ailenin şüphelenmesi, mağdurun olayı öğrenen arkadaşının itirafı, görgü tanığ1 ifadesi ve gebelik tespiti ile ortaya çıktı̆̆ 1 belirlenmiştir. $\mathrm{Bu}$ olayların yalnızca \%34,0'1 aynı gün adli makamlara 
yansımış olup, \%50,4'ü ilk 3 ayda, \%15,6'sı 3 aydan daha uzun bir zaman diliminde adli makamlara bildirilmiştir. İlk adli muayeneye kadar geçen süre ve tüm bu koşullar dikkate alındığında; cinsel istismarın tıbbi delili niteliğindeki bulgular kaybolmakta ve buna bağlı olarak sanığın kimliklendirmesi zorlaşmakta hatta yapılamamakta, mevcut bulgular hatalı değerlendirilmektedir (21).

Olguların \%33,4'ü olaydan sonraki ilk 3 ay içerisinde, \%21,5'i 4-6 ay içerisinde, $\% 25,9$ 'u $7-12$ ay içerisinde ve $\% 19,2$ 'si 13 ay ve sonrasında psikiyatrik muayene için müracaat ettirilmiştir. Yukarıda söz edilen nedenlerle meydana gelen bildirim gecikmesi ve olguların birkaç merkezde muayene edildikten sonra tarafimıza müracaat ettirilmesinin psikiyatrik değerlendirmedeki gecikmeye neden olduğunu düşünmekteyiz.

Çalışmamızda olguların \%16,3'ünde zeka düzeyi düşük olarak tespit edilmiștir. Zeka geriliği, psikiyatrik ve bedensel çeşitli rahatsızlıkların bulunması istismarcı açısından istismarı kolaylaştırıcı faktörler olup, mağdurun maruz kaldığ 1 eylemi tanımasında ve ifade etmesinde güçlük yaratan etkenlerdir $(12,22)$.
Gençler üzerinde yapılmış geniş olgu sayısına sahip çalışmalarda, cinsel istismara uğramış olan gençlerde uğramayanlara oranla daha fazla TSSB görüldüğü ve bu kişilerin daha depresif olduklarının tespit edildiği, cinsel istismara maruz kalan gençlerin \%75'inde stres, depresyon, kaygı ve suçluluk duygusu bulunduğu belirtilmektedir $(1,22-25)$. Çalışmamızda olguların \%37,8'inde psikiyatrik tanı ölçütlerini karşılayan ruhsal etkilenmenin bulunduğu tespit edilmiştir. Tanı konulan olguların \% 72,5 'inde TSSB, $\% 9,8$ 'inde depresyon ve $\% 11,7$ 'sinde TSSB ile depresyonun bir arada bulunduğu belirlenmiştir. Olgular, ruh sağlığı açısından şiddetli bozulma bulunup bulunmadığı, eğer bozulma var ise kalıcı olup olmadığı açısından değerlendirildiği, en erken 6 . ayda karara bağlandığ 1 ve genel olarak akut dönemde müracaat ettirilmediği için \% 60 oranında psikiyatrik tanı konulmadığ $\breve{l}$ kanaatindeyiz.

Çocuk ve ergenlerin cinsel istismarı sık görülen ve önemli bir halk sağlığ1 sorunu olup, sadece belli bir kısmı su yüzüne çıkmaktadır. Toplumda her kesimin bu konuda bilgilendirilmesi ve her basamakta önlemlerin alınması gerekmektedir. $\mathrm{Bu}$ önlemlerin belirlenebilmesi için daha fazla ve geniş çaplı çalışmalara ihtiyaç bulunmaktadır.

\section{KAYNAKLAR}

1. Çeçen AR. Çocuk cinsel istismarı sıklığı, etkileri ve okul temelli önleme yolları. Uluslararası İnsan Bilimleri Dergisi 2007; 4:1-17.

2. Davis,K.M.,Gidyez,C.A.Childsexualabusepreventio nprograms:Ameta-nalysis. Journal of Clinical Child Psychology 2000; 29:257-265.

3. Çöpür M, Üneri ÖŞ, Aydın E, Bahalı MK, Tanıdır C, Güneş H, Erdoğan A. İstanbul İli örnekleminde çocuk ve ergen cinsel istismarlarının karakteristik özellikleri. Anadolu Psikiyatri Derg 2012; 13:4650 .

4. PutnamFW Ten-yearresearchupdatereview: childsexualabuse. J Am Acad Child Adolesc Psychiatry 2003;42:269-278.

5. Yakut HI, Korkmaz E. Çocuklarda cinsel istismar. Jinekoloji-Obstetrik ve Neonatoloji T1p Dergisi 2013;10(39):1630-32.

6. Taner Y, Gökler B. Çocuk istismar ve ihmali: psikiyatrik yönleri. Hacettepe Tip dergisi 2004;35:82-86.

7. Johnson CF. Child sexualabuse. Lancet 2004;364:462-70.

8. GirardetRG,Lahoti S, ParksD, McNeeseM. İssues in pediatricsexualabuse-What we think we know and where we need to go.Curr Probl Pediatr Adolesc Health Care 2002;32(7):216-46.

9. Ovayolu N, Uçan Ö, Serindağ S. Çocuklarda cinsel istismar ve etkileri. Fırat Sağlık Hizmetleri Derg 2007;2:13-22.

10. www.tbmm.gov.tr/kanunlar/k5237.html

11. Fidan T, Ozan E, Algül S, Aydın N, Kırpınar I. Adli değerlendirme için getirilen cinsel istismara uğramış çocuk ve ergenlerin sosyodemografik özellikleri ve psikiyatrik tanıları. 17. Ulusal Çocuk ve Ergen Ruh Sağlığı ve Hastalıkları Kongresi 1922 Nisan 2007.

12. Şimşek Ş, Gençoğlan S. Cinsel istismar mağdurlarında istismar süresi ve sıklığı ile travma belirtileri arasındaki ilişkinin incelenmesi. Dicle Tıp Dergisi 2014;41(1): 166-171.

13. Davies EA, Jones AC. Risk factors in childsexualabuse. Journal of Forensic and Legal Medicine 2013;20(3):146-50.

14. Bilginer Ç, Hesapçıŏlu ST, Kandil S. Çocukluk çağı cinsel istismarı: Mağdur ve sanık açısından çok yönlü bakıș. Düşünen Adam The Journal of Psychiatry and Neurological Sciences 2013;26:5564. 
15. Dönmez YE, Soylu N, Özel Özcan Ö, Yüksel T, Çalışkan Demir A, Çon Bayhan P, Yıldız Miniksar D. Cinsel İstismar Mağduru Çocuk ve Ergen Olgularımızın Sosyodemografik ve Klinik Özellikleri. Turgut Ozal Med Cent 2014;21(1):448.

16. Pérez-Fuentes G, Olfson M, Villegas L, Morcillo $\mathrm{C}$, Wang S, Blanco C. Prevalence and correlates of child sexualabuse: a national study. Compr Psychiatry 2013;54(1):16-27.

17. Özer E, Bütün C,Beyaztaş YF, Engin A. Çorum adli tıp şube müdürlügü'ne 2006-2007 yıllarında başvuran cinsel istismar mağduru çocuk olgularının değerlendirilmesi. C.Ü. Tip Fakültesi Dergisi 2007;29(2):51-5.

18. Kirk C, Logie L, Mok JYQ Diagnosingsexualabuse (excludingforensics). Paediatrics and Child Health 2010;20(12):556-560.

19. Gökçe İmren S, Ayaz AB, Yusufoğlu C, Rodopman Arman A. Cinsel istismara uğrayan çocuk ve ergenlerde klinik özellikler ve intihar girișimi ile ilişkili risk etmenleri. Marmara Medical Journal 2013;26:11-16.
20. CohenLJ,GalynkerII.Clinical features of pedophilia and implications for treatment. J Psychiatr Pract 2002; 8:276-289.

21. Zengin BY, 9-17 Yaş Grubunda Cinsel İstismar Olgularının Adli Süreçte Yaşadıkları Örselenmenin Değerlendirilmesi ve Çözüm Önerileri 2014, Yayınlanmamış Uzmanlık Tezi

22. MurrayJB. Psychological profile of pedophiles and child molesters. J Psychol 2000;134:211-224.

23. Kellog N. The evaluation of sexual abuse in children. Pediatrics 2005;25:506-512.

24. Karakaya I, Coşkun A,Ağaoğlu B,Şişmanlar ŞG, Öç Yıldız Ö, Memik Çakın N, Biçer Ü. Cinsel İstismara Maruz Kaldığı Bildirilen Olguların Ruhsal Değerlendirme Sonuçları. Adli Tıp Bülteni 2006;11(2):53-58.

25. BoneyMcCoyS, Finkelhor D. Prior victimization: a risk factor for child sexual abuse and for PTSDrelated symptomatology among sexually abused youth. Child Abuse and Neglect 1995;19(12):14011421. 